\title{
ONE- AND TWO-DIMENSIONAL ECOHYDRAULIC MODELING OF FORMOSO
} RIVER (MG)

Doi:http://dx.doi.org/10.1590/1809-4430-Eng.Agric.v36n6p1050-1062/2016

\section{IARA DE C. E OLIVEIRA ${ }^{1 *}$, DEMETRIUS D. DA SILVA², HUGO A. S. GUEDES ${ }^{3}$, JORGE A. DERGAM ${ }^{2}$, CELSO B. DE M. RIBEIRO ${ }^{4}$}

${ }^{1 *}$ Corresponding author. Universidade Federal de Viçosa/Viçosa - MG, Brasil. E-mail: iaracasoli@ yahoo.com.br

ABSTRACT: The objective of this study was to compare ecohydrological simulations from a onedimensional model (PHABSIM - Physical Habitat Simulation System) and a two-dimensional model (River2D) in order to indicate a reliable tool that could be used to determine public policies for the sustainable management of the water resources of the Formoso River basin (MG). The results from the calibration of hydraulic variables, namely, water depth and velocity, as well as habitat predictions for three fish species of the river were compared. The results showed that River2D was best suited to simulate ecohydrological features for the studied river stretch. Although PHABSIM presented a better fit of the hydraulic variables at the calibration process, the use of only three monitoring cross sections to compose the biotic model database compromised its habitat modeling. PHABSIM model was not able to accurately assess the actual characteristics of the physical habitat in the segments of the river located between the monitoring cross sections.

KEYWORDS: PHABSIM, River2D, weighted usable area, water resources.

\section{INTRODUCTION}

Brazil occupies a privileged environmental position due to the volume and availability of water. However, the increasing use of water resources contributed to the loss of biodiversity and ecological integrity of such environments (ARAI et al., 2012; VOROSMARTY et al., 2010). Human activities associated with the use of water led to a number of morphological changes in the watercourses (TUHTAN et al., 2012), reducing their heterogeneity and, consequently, the availability of adequate physical habitats for aquatic species (HOLMQUIST \& WADDLE, 2013).

In this context, the use of instream habitat models (TONINA \& JORDE, 2013; ZALEWSKI, 2010) is important, as they integrate hydraulic and biological models to predict the available habitat for aquatic species as a function of flow variation (IM et al., 2011). It is possible to find models that use different techniques, such as diffuse, multivariate and fuzzy logic approaches, and that allow the inclusion of the interaction between ecological variables (BOAVIDA et al., 2014; BENJANKAR et al., 2012; DARAIO et al., 2010; SILVA, 2010), including water quality parameters, such as temperatures, dissolved oxygen levels, biochemical oxygen demands and nutrients (SOUZA et al., 2014; MARSILI-LIBELLI et al., 2013; AYLLÓN et al., 2012b), among other potentialities. Such models vary in complexity, from one-dimensional models (GOTO et al., 2015) to those based on two- (YI et al., 2010) or three-dimensional hydraulic equations (DARAIO et al., 2010).

Among the one-dimensional models for hydraulic and aquatic habitat simulations, the PHABSIM (Physical Habitat Simulation System) is optimal (MILHOUS et al., 1989), as it is widely used in ecohydrologic studies worldwide (AYLLÓN et al., 2012a; LEE et al., 2010, GARD, 2009).

Among the existing two-dimensional models, River2D (STEFFLER \& BLACKBURN, 2002) is the most commonly used in aquatic habitat modeling studies (FUKUDA et al., 2014; HOLMQUIST \& WADDLE, 2013; BOAVIDA et al., 2012; PARASIEWICZ et al., 2012; IM et al., 2011).

\footnotetext{
${ }^{2}$ Universidade Federal de Viçosa/Viçosa - MG, Brasil.

${ }^{3}$ Universidade Federal de Pelotas/Pelotas - RS, Brasil.

${ }^{4}$ Universidade Federal de Juiz de Fora/ Juiz de Fora - MG, Brasil.

Received in: 5-25-2015

Accepted in: 7-8-2016
} 
PHABSIM and River2D models employ the instream flow incremental methodology (BOVEE et al., 1998) to simulate the available habitat in watercourses. The results are given in values of weighted usable area (WUA), which represents the area of available habitat for each aquatic species and flow of interest.

According to JOWETT \& DUNCAN (2012), in theory, physics applied to two-dimensional models were more efficient in modeling watercourses that featured complex riverbeds with obstructions, islands, and meanders than the one-dimensional models, as the use of two-dimensional models recognized transverse variations on the water level so that different morphological characteristics, such as pools and rifles, could be modeled. However, despite being able to predict variation in complex flow situations, some studies showed that two-dimensional models did not necessarily predict depth and velocity values more accurately than one-dimensional models (WADDLE et al., 2000). Thus, the choice of the model to be applied in each study should take into account a number of variables, such as cost, precision of the hydraulic variables that make up the physical habitat and morphological characteristics of the studied watercourse.

One- and two-dimensional models applied to ecohydrologic studies are considered to be promising tools to outline policies and water resources' management (GORLA \& PERONA, 2013; MILLIDINE et al., 2012; FRANK et al., 2011). However, in Brazil, the records of studies involving ecohydrologic modeling in watersheds are still scarce (CASTRO et al., 2016; GUEDES et al., 2014).

The objective of this study was to compare ecohydrologic simulations from a onedimensional model (PHABSIM) and a two-dimensional model (River2D) in order to find a reliable tool that could be used to determine public policies for sustainable management of the water resources of the Formoso River basin (MG).

\section{MATERIAL AND METHODS}

\section{Study site}

Formoso River, a right bank tributary of Pomba River, is $76.7 \mathrm{~km}$ long, with an average slope of $0.0014 \mathrm{~m} / \mathrm{m}$ and a drainage area of $398 \mathrm{~km}^{2}$. The river flows in the western region of the Paraíba do Sul River basin, between parallels $21^{\circ} 18^{\prime} \mathrm{S}$ and $21^{\circ} 27^{\prime} \mathrm{S}$ and meridians $43^{\circ} 10^{\prime} \mathrm{W}$ and $43^{\circ} 38^{\prime} \mathrm{W}$ in the state of Minas Gerais (Figure 1). 


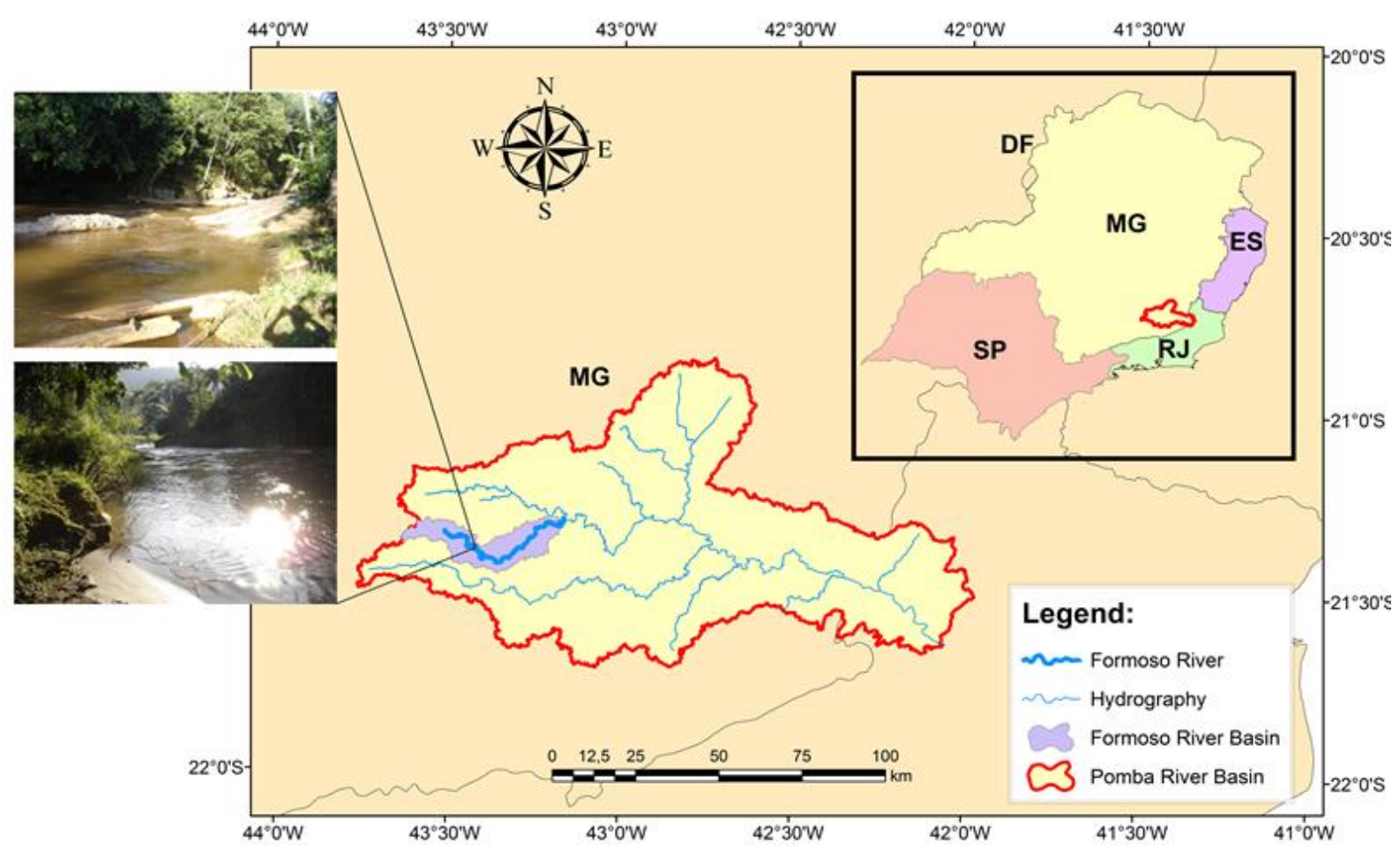

FIGURE 1. Geographical location of the Formoso River basin.

A 1-km long study site was selected that was located on the steep portions of the basin. The site was characterized by the areas of preserved forest, the presence of riparian vegetation, and the absence of urbanization.

\section{Data survey}

Four field campaigns were conducted at Formoso River over a period of two years, with two campaigns in drought seasons (June 2011 and July 2012) and two in rainy seasons (March 2011 and February 2012) to quantify hydraulic, hydrologic, and biological variables in order to calibrate the hydrologic models in question.

Three monitoring cross sections were demarcated, equally spaced 500 meters from each other, totaling a 1-km long stretch. At these cross sections, the water depths, velocities, and substrate compositions were measured at 1-m intervals. Flows were measured at the beginning of the studied stretch in each campaign as follows: $6.41 \mathrm{~m}^{3} \mathrm{~s}^{-1}$ (03/2011), $3.62 \mathrm{~m}^{3} \mathrm{~s}^{-1}(06 / 2011), 6.15 \mathrm{~m}^{3} \mathrm{~s}^{-1}$ $(02 / 2012)$ and $3.29 \mathrm{~m}^{3} \mathrm{~s}^{-1}(07 / 2012)$. All the data were used to calibrate both models.

For substrate (bottom river material) characterization, a dredge sampler was used. The collected material was analyzed at the Physical Properties of Soil Laboratory, from the Soil Department of the Federal University of Viçosa (UFV) and was used in order to determine the particle size and average aggregate diameter $\left(\mathrm{D}_{50}\right)$.

Biotic data were obtained from the fish species that were characteristic of Formoso River. Seven gill-nets, with 0.015-, 0.020-, 0.025-, 0.030-, 0.035-, 0.040- and 0.050-m meshes were equally and randomly spaced 10 meters apart and positioned to capture specimens in the studied river stretch (GUEDES et al., 2014).

A topo-bathymetric survey of the studied site was conducted in June 2012 with a Total Station equipment. The bathymetric profile was demarcated with $10 \times 10 \mathrm{~m}^{2}$ cross sections in addition to points located on the banks of the watercourse, enabling georeferencing of the information. The survey in question had an average density of measurement points equivalent to 16 per $100 \mathrm{~m}^{2}$, yielding a total of 1,578 points. 


\section{One-dimensional modeling}

For the one-dimensional modeling, the river segment is treated as a set of cross sections, for which the water depth and average velocity based on the hydraulic and morphological principals of the channel were calculated. It is also assumed that the flow regime is uniform and that only spatial variations along the longitudinal section of the channel are considered (TONINA \& JORDE, 2013). The same cross sections used to obtain the hydraulic variables are also used for the biotic monitoring, with the capture of fish species.

The employment of one-dimensional models is criticized due to the following limitations:

I) When assuming uniform flow values, such models are not able to reproduce/simulate flows that spatially vary, such as meanders, islands, velocity gradients and transverse flows (CROWDER et al., 2004);

II) The results of the hydraulic modeling significantly vary due to the localization and number of cross sections that are used to compose the modeling process (KONDOLF et al., 2000); and

III) The models ignore convective accelerations, which are derived from significant changes in velocity due to alterations on the channel shape.

PHABSIM is a software composed by a set of one-dimensional models that are based on the assumption that hydraulic environmental attributes, such as water depth and velocity, vary according to incremental alterations on the flow. These alterations cause changes in the quantity and quality of the available habitat for the species of interest of local aquatic biota. (SANTOS et al., 2009).

Two sets of variables are required for PHABSIM hydraulic modeling: data of the channel structure, including bathymetry, distance between cross sections and substrate (bottom river material) characteristics, and hydraulic data, such as water depth and velocity. The model represents the segment of river as a set (mosaic) of cells. The size of these cells is determined by the number of cross sections that represent the river segment, as well as the number of verticals measured in each cross section. Each cell has a combination of flow, depth, velocity and substrate data.

The model employed the length weighting factor that determines the representativity of each cross section on the watercourse upstream and downstream segments, longitudinally delimiting the cell sizes that compose the studied river stretch, which values may vary from $0(0 \%)$ to $1(100 \%)$ (USGS, 2001). In this study, length weighting factors of 0 and 5 were used for each cross section. Considering that the data acquisition was performed at $1 \mathrm{~m}$ intervals along each cross section, the cell areas obtained for the modeled stretch of the river were equivalent to 250 and $500 \mathrm{~m}^{2}$.

The calibration of flow depth was the first step conducted in hydraulic modeling. To determine the relationship between water depth and the corresponding flow, the hydraulic model used Manning's equation - the MANSQ Model (USGS 2001). The input data included the cross section profile, bed slope, calibration flow and corresponding water level, thereby calculating the hydraulic radius, cross sectional area and friction factor.

The second step of the hydraulic modeling involved simulation of the velocity profile of each monitoring cross section. The velocity profiles measured in the four field campaigns at each monitoring cross section were used as input data for the VELSIM model, which belonged to the PHABSIM software suite. Once again, the modeling employed Manning's equation from one calibration flow data (Equation 1). When another flow was simulated, the model obtained the water level depth for this flow, which resulted in new values of depth for the cross section verticals $\left(\mathrm{d}_{i^{\prime}}\right)$. These values were substituted into Manning's equation to obtain velocity estimates for each vertical (Equation 2):

$$
\mathrm{n}_{\mathrm{i}}=\frac{1,49}{\mathrm{v}_{\mathrm{i}}} \times \mathrm{d}_{\mathrm{i}}^{2 / 3} \times \mathrm{S}^{1 / 2}
$$




$$
\mathrm{v}_{\mathrm{i}}=\frac{1,49}{\mathrm{n}_{\mathrm{i}}} \times \mathrm{d}_{\mathrm{i}^{\prime}}^{2 / 3} \times \mathrm{S}^{1 / 2}
$$

where,

$\mathrm{n}_{\mathrm{i}}$ is the roughness coefficient for vertical $\mathrm{i}\left(\mathrm{m}^{-1 / 3} . \mathrm{s}\right)$;

$v_{i}$ is the calibration velocity (measured) for vertical $\mathrm{i}\left(\mathrm{m} . \mathrm{s}^{-1}\right)$;

$\mathrm{d}_{\mathrm{i}}$ is the vertical i depth (difference between the riverbed level and the water level) (m), and

$\mathrm{S}$ is the average bed slope on the section of interest $\left(\mathrm{m} \cdot \mathrm{m}^{-1}\right)$.

\section{Two-dimensional modeling}

For two-dimensional modeling, the flow velocity is variable in both longitudinal and transverse directions. The riverbed is discretized in a triangulation irregular network (TIN) mesh (KASER et al., 2014) for the preparation of a finite element mesh. The values of depth and two horizontal components of velocity are obtained for each calculation point. These values are interpolated from nodes belonging to the mesh elements to produce a continuous flow field along the watercourse (TONINA \& JORDE, 2013).

Two-dimensional models have great potential for ecohydrologic studies because they predict the geometric flexibility associated with the fine elements' modeling, which may easily change the size and shape of the meshes and allow its refinement in areas of great interest or in more complex configuration. Thus, these models are able to represent habitats that include transverse flows, velocity gradients and depth variation of the flow stream. However, their greatest source of error is related to data interpolation, particularly when there is a wide variation between the surrounding conditions of a specific mesh node (STEFFLER \& BLACKBURN, 2002).

The hydrodynamic component of the River2D model is based on the two-dimensional, depthaveraged St. Venant equations, which is expressed in a conservative form: the conservation of the mass equation (Equation 3) and the conservation of momentum $x$ (Equation 4) and y (Equation 5). The dependent variables are depth and discharge intensities in the two respective coordinate directions (STEFFLER \& BLACKBURN, 2002):

$$
\begin{aligned}
& \frac{\partial H}{\partial t}+\frac{\partial q_{x}}{\partial x}+\frac{\partial q_{y}}{\partial y}=0 \\
& \frac{\partial \mathrm{q}_{\mathrm{x}}}{\partial \mathrm{t}}+\frac{\partial}{\partial \mathrm{x}}\left(\mathrm{Uq}_{\mathrm{x}}\right)+\frac{\partial}{\partial \mathrm{y}}\left(\mathrm{Vq}_{\mathrm{x}}\right)+\frac{\mathrm{g}}{2} \frac{\partial}{\partial \mathrm{x}} \mathrm{H}^{2}=\mathrm{gH}\left(\mathrm{S}_{0 \mathrm{x}}-\mathrm{S}_{\mathrm{fx}}\right)+\frac{1}{\rho}\left(\frac{\partial}{\partial \mathrm{x}}\left(\mathrm{H} \tau_{\mathrm{xx}}\right)\right)+\frac{1}{\rho}\left(\frac{\partial}{\partial \mathrm{y}}\left(\mathrm{H} \tau_{\mathrm{xy}}\right)\right) \\
& \frac{\partial \mathrm{q}_{\mathrm{y}}}{\partial \mathrm{t}}+\frac{\partial}{\partial \mathrm{x}}\left(\mathrm{Uq}_{\mathrm{y}}\right)+\frac{\partial}{\partial \mathrm{y}}\left(\mathrm{Vq}_{\mathrm{y}}\right)+\frac{\mathrm{g}}{2} \frac{\partial}{\partial \mathrm{y}} \mathrm{H}^{2}=\mathrm{gH}\left(\mathrm{S}_{0 \mathrm{y}}-\mathrm{S}_{\mathrm{fy}}\right)+\frac{1}{\rho}\left(\frac{\partial}{\partial \mathrm{x}}\left(\mathrm{H} \tau_{\mathrm{yx}}\right)\right)+\frac{1}{\rho}\left(\frac{\partial}{\partial \mathrm{y}}\left(\mathrm{H} \tau_{\mathrm{yy}}\right)\right)
\end{aligned}
$$

where,

$H$ is the depth of flow [L];

$\mathrm{U}$ and $\mathrm{V}$ are the depth-averaged velocities in the $x$ and $y$ coordinate directions, respectively $\left[\mathrm{L} \mathrm{T}^{-1}\right]$

$\mathrm{q}_{\mathrm{x}}$ and $\mathrm{q}_{\mathrm{y}}$ are the respective discharge intensities which are related to the velocity components; $\mathrm{g}$ is the acceleration due to gravity $\left[\mathrm{L} \mathrm{T}^{-2}\right]$;

$\rho$ is the density of water $\left[\mathrm{M} \mathrm{L}^{-3}\right]$;

$\mathrm{S}_{0 \mathrm{x}}$ and $\mathrm{S}_{0 \mathrm{y}}$ are the bed slopes in the $x$ and $y$ directions, respectively [ $\mathrm{L} \mathrm{L}^{-1}$ ];

$\mathrm{S}_{\mathrm{fx}}$ and $\mathrm{S}_{\mathrm{fy}}$ are the corresponding friction slopes $\left[\mathrm{L} \mathrm{L}^{-1}\right]$, and 


$$
\tau_{\mathrm{xx}}, \tau_{\mathrm{xy}}, \tau_{\mathrm{yx}} \text { and } \tau_{\mathrm{yy}} \text { are the components of the horizontal turbulent stress tensor }\left[\mathrm{L}^{2} \mathrm{~T}^{-1}\right] .
$$

Among the four modules of River2D, three were sequentially employed: River Bed, River Mesh and River2D. The modeling process involved the creation and edition of the channel and its surroundings topographic data on the River Bed module, the generation of a finite element mesh on the River Mesh module and the performance of hydraulic and habitat simulations for the created mesh on the River2D module.

The River Bed module used the topo-bathymetry survey and distribution of roughness (substrate composition) information for the creation of computational nodes, for which values of $\mathrm{x}$ and y geographic coordinates, bed elevation, and effective roughness $\left(\mathrm{k}_{\mathrm{s}}\right)$ were supplied.

Then, River Mesh was employed to generate a computational mesh, which was necessary to introduce the river bed topography archive that was previously created and edited on River Bed. At this step, a fine element mesh was generated from a triangular irregular network mesh. Later, it was necessary to refine the computational mesh through successive operations of edition, with an assessment of its quality conducted by evaluating the quality index (QI) variable. This variable was defined as the ratio between the area of each triangle mesh and its circumcircle. The value for each mesh represented the minimum quality of one triangle in relation to the other triangles of the mesh. According to WADDLE \& STEFFLER (2002), satisfactory values of mesh refinement were represented by QI between 0.1 and 0.5 . In this study, the value was 0.4 . The mesh generated at the end of this process had an average size cell equal to $6.0 \mathrm{~m}^{2}$.

\section{Models' calibration and habitat simulation}

The hydraulic simulations composed the calibration of PHABSIM and River2D, and the results were compared using the following indices: coefficient of determination $\left(\mathrm{R}^{2}\right)$, Willmott index of agreement (d) and mean absolute error (MAE) (JAY LACEY \& MILLAR, 2004; CHOU \& CHUANG, 2010).

The results of the habitat modeling of both models were given by the production of WUA versus flow curves relative to different percentages $(10 \%, 20 \%, 30 \%, 40 \%, 50 \%, 60 \%, 70 \%, 80 \%$, $90 \%$, and $100 \%$ ) of the long-term mean flows of drought, normal and rainy seasons from the studied river stretch that were generated for fish species Hypostomus aurogutattus in both juvenile and adult stages and Leporinus mormyrops and Oligosarcus hepsetus, in the adult stage only. These species were considered to be characteristic of Formoso River and sensitive to changes in the flow regime. The juvenile stages of $L$. mormyrops and $O$. hepsetus were not considered in this study because they were not found in a representative number of specimens during the field campaigns (less than five specimens considering all the data collection) at that life stage.

The WUA values were produced by relating different flows of Formoso River with the habitat suitability index (HSI) curves (GUEDES et al., 2014; BOVEE et al., 1998). For the elaboration of these curves, a record of the fish species and number of its individuals who were captured at each monitoring cross section and field campaign was made in order to associate them to the following morphologic and hydrologic characteristics of the monitoring cross sections: average water velocity, average water depth and substrate type. The HSI were obtained through the statistical technique of frequency histogram and then curves for each variable of interest for each fish species were developed. Therefore, the corresponding data of each variable was grouped into graded intervals that were determined by the Sturges' formula (PELISSARI, 2000). The maximum value of HIS, which was equivalent to 1 , was assigned to the interval(s) with the greatest number of individuals of the species of interest. Then, values between 0 and 1 were assigned to the other intervals, according to the relative proportion between the number of interval individuals and the maximum number of individuals of the species found at an interval. The habitat suitability curves were then developed by connecting the midpoints relative to each grade interval. 


\section{RESULTS AND DISCUSSION}

\section{Models' calibration}

Figure 2 presents the results of the performance of the calibration of the PHABSIM and River2D models. The statistical indices $\left(\mathrm{R}^{2}, \mathrm{~d}\right.$, and MAE) used for the validation of these results are detailed in Table 1.

Figure 2 and Table 1 show that PHABSIM exhibited a better adjustment between observed and predicted data than River2D, according to the three statistical indices considered in this study. Considering all the ordered pairs of predicted and observed data, in general, the performance of both models tended to underestimate the values of the hydraulic variables. For the majority of the analyzed points, the predicted values of water velocity and depth were lower than the observed values.
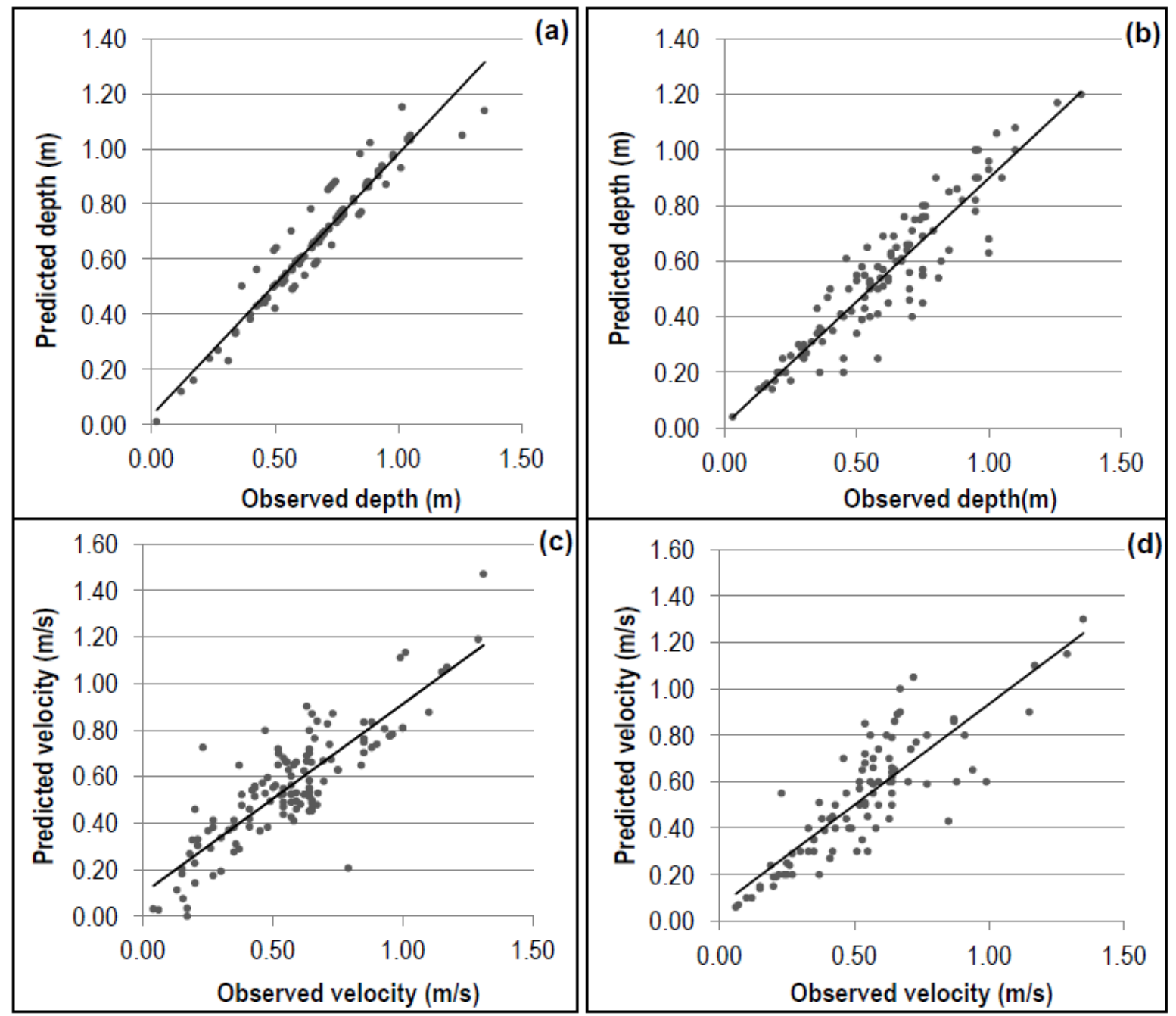

FIGURE 2. Comparison of observed and predicted data using PHABSIM (a, c) and River2D (b, d) models for the monitored stretch of Formoso River. 
TABLE 1. Predicted water depths and velocities' statistical indices obtained from PHABSIM and River2D models.

\begin{tabular}{ccccccccc}
\hline \multirow{2}{*}{ Model } & \multicolumn{3}{c}{ Depth } & & \multicolumn{3}{c}{ Velocity } \\
\cline { 2 - 3 } \cline { 6 - 8 } & $\mathrm{R}^{2}$ & $\mathrm{~d}$ & $\operatorname{MAE}(\%)$ & & $\mathrm{R}^{2}$ & $\mathrm{~d}$ & MAE (\%) \\
\hline PHABSIM & 0,93 & 0,98 & 4,9 & & 0,77 & 0,95 & 20,3 \\
River2D & 0,85 & 0,95 & 13,4 & & 0,68 & 0,90 & 21,2 \\
\hline
\end{tabular}

BOAVIDA et al. (2012) stated that the difference between the cross sections considered by the River2D model, which were obtained with the finite element mesh, could significantly influence the fit between the simulated and observed values of the hydraulic variables. The PHABSIM survey depth predictions and cross section profiles were very similar to the observed data because data points were collected along the exact same cross sections. Not surprisingly, there was less fit between River2D depth predictions and cross section profiles and the observed data, with the River2D profiles being smoother than the field measurements due to its finite element mesh model composition. JOWETT \& DUNCAN (2012), in a study on the Hurunui River (New Zealand), observed this same behavior, obtaining values of $\mathrm{R}^{2}$ equivalent to 0.96 and 0.83 for the fit of depth between observed and simulated values, which were obtained by PHABSIM and River2D models, respectively, as well as values of the mean absolute error of $8 \%$ and $22 \%$, respectively, for the fit of depth between observed and simulated values.

The lower fit between the observed and simulated velocity data related to the River2D modeling was due to this sensitivity to changes in the morphology of the riverbed of this variable. Therefore, this lower fit was due to likely alterations in the bed morphology in the studied stretch in the period between the field measurements of that variable and the topo-bathymetry survey used to compose the finite element mesh.

However, the calculated values for the statistical indices in question indicated fits matching those found in other studies, for both water depth and velocity variables. In a study of a 50-m stretch from the Bere stream (UK), BOOKER et al. (2004) found flows between $0.45 \mathrm{~m}^{3} \mathrm{~s}^{-1}$ and $1.01 \mathrm{~m}^{3} \mathrm{~s}^{-1}$ and a value of 0.67 for $\mathrm{R}^{2}$ on the velocity's hydraulic modeling. GALLAGHER (1999) found flows between $15 \mathrm{~m}^{3} \mathrm{~s}^{-1}$ and $60 \mathrm{~m}^{3} \mathrm{~s}^{-1}$ in a study of the Trinity River, California (USA), and KONDOLF et al. (2000) found flows between $1.16 \mathrm{~m}^{3} \mathrm{~s}^{-1}$ and $7.45 \mathrm{~m}^{3} \mathrm{~s}^{-1}$ in a study of the William Fork River, Colorado (USA). Both of these studies reported MAE values close to $15 \%$ on the onedimensional models. JOWETT \& DUNCAN (2012) obtained values of $18 \%$ and $34 \%$ for that same index using PHABSIM and River2D models, respectively.

\section{Habitat simulation}

Figure 3 presents the WUA versus flow curves produced by PHABSIM and River2D models for fish species $H$. aurogutattus (juvenile and adult stages), L. mormyrops (adult stage) and $O$. hepsetus (adult stage). 

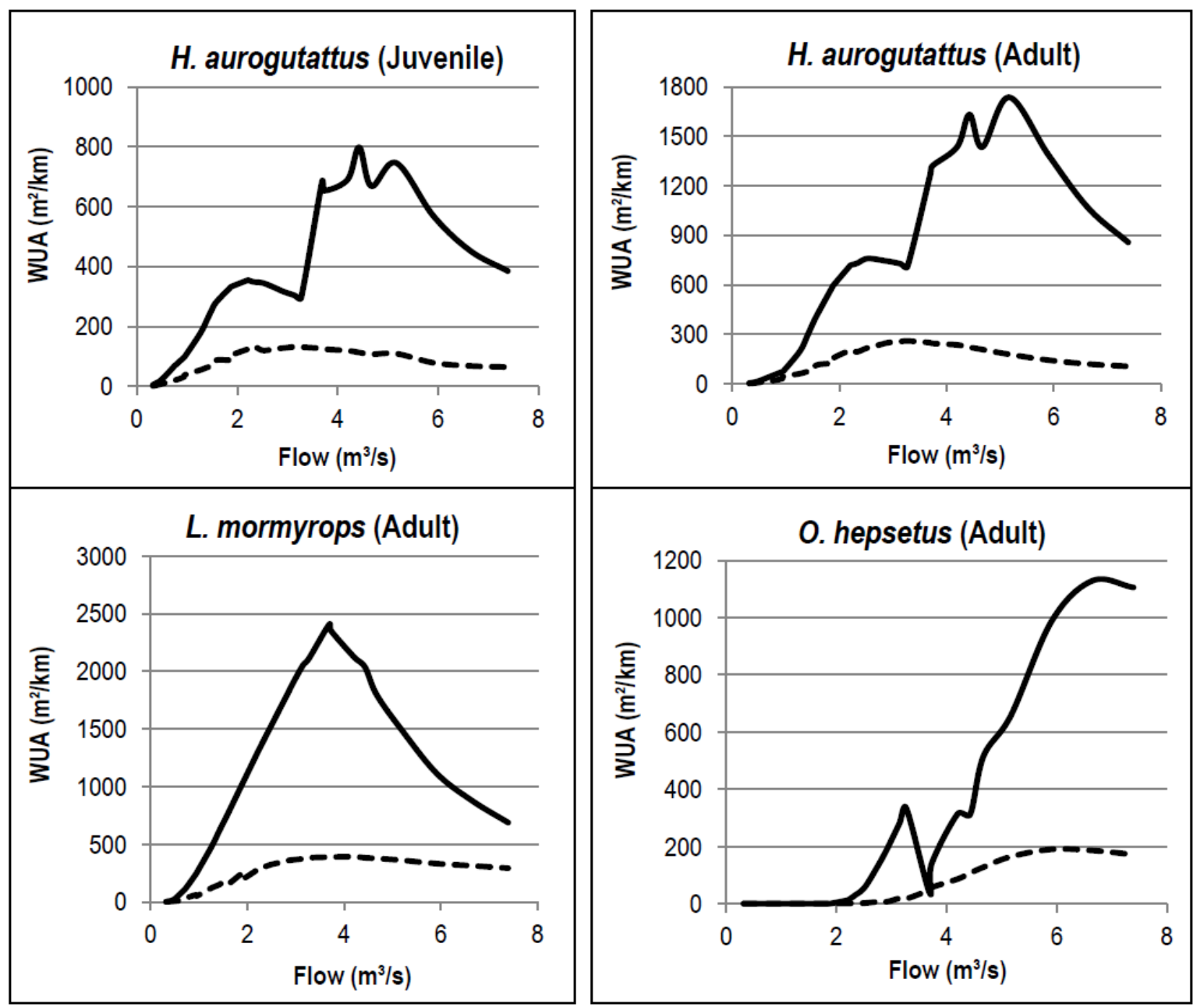

FIGURE 3. Weighted usable area (WUA) curves for the studied fish species using PHABSIM (solid line) and River2D (dashed line) models.

The curves produced by both models presented, overall, the same tendency. However, the magnitude of the simulated WUA values substantially varied between the models, in a way that the PHABSIM curves presented expressively higher values for HSI for all studied fish species, with no consistent variation pattern identified. The difference in the habitat modeling process between the one- and two-dimensional models, which implied the production of distinct values of WUA, could essentially be attributed to the size of the computational cells. The River2D model approached the flow profile as a TIN mesh, in which the cell size was determined according to the discretization of the finite element mesh. The PHABSIM model used a cell size that was relative to the proportion equivalent to the representativeness of each monitoring cross section to the extent of the river stretch under study, both in upstream and downstream directions, which was defined by the user.

In this study, the use of three monitoring cross sections, equally spaced 500 meters apart, yielded one-dimensional calculation cells whose area values were notably high $\left(250\right.$ and $\left.500 \mathrm{~m}^{2}\right)$, providing two opposite consequences to their results:

- when the modeled hydraulic variable (depth, velocity, or channel index assigned to each cell) had a high Habitat Suitability Index (HSI) value for a certain species, this value was attributed to the entire segment between the monitoring cross sections (corresponding to the cell size), contributing to high values of WUA; and

- when the modeled hydraulic variable had a low (or null) HSI value for a given species, this value was attributed to the entire segment between the monitoring cross sections (corresponding to the cell size), contributing to the low values of WUA for the studied river stretch. 
The River2D model, due to the composition process of its mesh cells, had smaller cell sizes and a considerably greater number of calculation cells than the PHABSIM model, which contributed to a more accurate characterization of the variation in velocity, depth, and substrate profiles, specifically on the segments between the monitoring cross sections of the studied stretch of Formoso River.

The studied stretch of Formoso River is characterized as steep, with varying profiles of depth, velocity, and substrate, and bearing pools and riffles along its length. However, the PHABSIM model, when considering only the characteristics of three cross sections, made it impossible to characterize such variations accurately throughout the watercourse profile. According to LORANGER \& KENNER (2004), the discrepancy between one- and two-dimensional WUA values is a function of the overestimation or underestimation of habitats when considering a small number of monitoring cross sections to represent the length of a watercourse.

Therefore, for the application of PHABSIM, a number of cross sections should be used that is sufficiently able to represent, as accurately as possible, the variation of the flow profile along the river channel, with respect to the hydraulic variables considered (GALLAGHER, 1999). However, it is worthy to note that the small number of monitoring cross sections used in this study was due to the available resources and the feasibility of the monitoring activities in the field, revealing a relevant limitation of the PHABSIM model in defining the size of its calculation cells, especially in regard to the practical aspects associated with data acquisition to calibrate the model.

$\mathrm{OH}$ et al. (2008) attributed the difference between the magnitudes of WUA versus flow curves to the difference in the size of the computational cells that made up the one- and two-dimensional models, when the mean cell sizes equivalent to $128 \mathrm{~m}^{2}$ and $6.45 \mathrm{~m}^{2}$ for PHABSIM and River2D, respectively, were considered.

The differences between the results of the models reflected the different hydraulic approaches of each one. The River2D model has data acquisition and calibration processes that are more expensive and time-consuming than the PHABSIM model. However, modeling by means of PHABSIM was only sufficient in situations in which the river channel does not have complex hydrodynamic characteristics or when it is feasible to conduct an accurate survey considering a number of cross sections that are able to effectively characterize all the different habitats of the channel, due to the variation in water velocity, depth, and substrate profiles along its length, or in situations in which it is technical and economically feasible to conduct a field survey in several cross sections, where it is possible to measure all the necessary hydraulic, morphological and habitat variables.

If performed correctly, one- and two-dimensional modeling should produce similar results, thus confirming, as GARD (2009) and JOWETT \& DUNCAN (2012) showed, that one- and twodimensional models showed comparable accuracy, although the two-dimensional model is potentially capable of simulating more complex flow patterns.

\section{CONCLUSIONS}

This study concluded that the River2D model was best suited to simulate ecohydrologic features for Formoso River (MG). Although PHABSIM presented a better fit to the hydraulic variables at the calibration process, the use of only three monitoring cross sections to compose the biotic model database compromised its habitat modeling. PHABSIM was not able to accurately assess the actual characteristics of the physical habitat in the segments of the river located between the monitoring cross sections.

\section{ACKNOWLEDGEMENTS}

The authors acknowledge the financial support granted by the National Council of Technological and Scientific Development (CNPq) through the first author's scholarship, which enabled this study, and by the Research Support Foundation of Minas Gerais State (FAPEMIG). 


\section{REFERENCES}

ARAI, F. K.; PEREIRA, S. B.; GONÇALVES, G. G. G. Characterization of water availability in a hydrographic basin. Engenharia Agrícola, Jaboticabal, v.32, n.3, p.591-601, maio/jun. 2012.

AYLlÓN, D.; ALMODÓVAR, A.; NICOLA, G.G.; PARRA, I.; ELVIRA, B. A new biological indicator to assess the ecological status of Mediterranean trout type streams. Ecological Indicators, Amsterdam, v.20, p.295-303, set. 2012a.

AYLLÓN, D.; ALMODÓVAR, A.; NICOLA, G.G.; PARRA, I.; ELVIRA, B. Modelling carrying capacity dynamics for the conservation and management of territorial salmonids. Fisheries Research, Amsterdam, v.134-136, p.95-103, dez. 2012b.

BENJANKAR, R.; JORDE, K.; YAGER, E.; GOODWIN, P.; GLENN, N. F. Impact of river modification and dam operation on floodplain vegetation succession trend in the Kootenai River, USA. Ecological Engineering, Amsterdam, v.46, p.88-97, set. 2012.

BOAVIDA, I.; DIAS, V.; FERREIRA, M.T.; SANTOS, J.M.Univariate functions versus fuzzy logic: Implications for fish habitat modeling. Ecological Engineering, Amsterdam, v.71, p.533538. 2014.

BOAVIDA, I.; SANTOS, J.M.; KATOPODIS, C.; FERREIRA, M.T.; PINHEIRO, A. Uncertainty in predicting the fish-response to two-dimensional habitat modeling using field-data. River Research and Applications, Chichester, v.29, p. 1164-1174. 2012.

BOOKER, D.J.; DUNBAR, M.J.; IBBOTSON, A. Predicting juvenile salmonid drift-feeding habitat quality using a three-dimensional hydraulic-bioenergetic model. Ecological Modelling, New York, v.177, p.157-177, 2004.

BOVEE, K.; LAMB, B.; BARTHOLOW, J.; STALNAKER, C.; TAYLOR, J.; HENRIKSEN, J. Stream habitat analysis using the instream flow incremental methodology. Fort Collins: Geological Survey, 1998. 130 p.

CASTRO, E. R. R.S.; MOREIRA, M.C.; SILVA, D.D. Environmental flow in the River Ondas basin in Bahia, Brazilian Cerrado. Environmental Monitoring and Assessment, Dordrecht, v.188, p.68-77, 2016.

CHOU, W-C; CHUANG, M-D. Habitat evaluation using suitability index and habitat type diversity: a case study involving a shallow forest stream in central Taiwan. Environmental Monitoring and Assessment, Dordrecht, v.172, n.1-4, p.689-704. doi 10.1007/s10661-010-1364-0. 2010.

CROWDER, D. W.; DIPLAS, P.; SHEN, Y. Hydraulic habitat metrics: quantifying spatially explicit flows. In: INTERNATIONAL SYMPOSIUM ON ECOHYDRAULICS, 5., 2004, Madrid. Proceedings... Madrid: IAHR, 2004.

DARAIO, J.A.; WEBER, L.J.; NEWTON, T.J.; NESTLER, J.M. A methodological framework for integrating computational fluid dynamics and ecological models applied to juvenile freshwater mussel dispersal in the Upper Mississippi River. Ecological Modelling, New York, v.221, p.201214. 2010.

FRANK, B.M.; PICCOLO, J.J.; BARET, P.V. A review of ecological models for brown trout: towards a new demogenetic model. Ecology of Freshwater Fish, Copenhagen, v.20, p.167-198, 2011.

FUKUDA, S.; TANAKURA, T.; HIRAMATSU, K.; HARADA, M. Assessment of spatial habitat heterogeneity by coupling data-driven habitat suitability models with a 2D hydrodynamic model in small-scale streams. Ecological Informatics, Netherlands, 2014. Disponível em: <www.sciencedirect.com>. Aceso em: 27 fev. 2015. doi:10.1016/j.ecoinf.2014.10.003

GALLAGHER, S.P. Use of two dimensional hydrodynamic modeling to evaluate channel rehabilitation in the Trinity River, California, USA. Arcata: U.S. Fish Wildlife Service, 1999. 36 p. 
GARD, M. Comparison of spawning habitat predictions of PHABSIM and River2D models. International Journal of River Basin Management, Madrid, v.7, n.1, p.55-71, ago. 2009.

GORLA, L.; PERONA, P. On quantifying ecologically sustainable flow releases in a diverted river reach. Journal of Hydrology, Amsterdam, v.489, p.98-107, may. 2013.

GOTO, D.; HAMEL, M.J.; HAMMEN, J.J.; RUGG, M.L.; PEGG, M.A.; FORBES, V.E. Spatiotemporal variation in flow-dependent recruitment of long-lived riverine fish: Model development and evaluation. Ecological Modelling, New York, v.296, p.79-92, jan. 2015.

GUEDES, H. A. S.; SILVA, D. D.; DERGAM, J. A.; ELESBON, A. A. A. Estabelecimento do regime de vazões ecológicas no Rio Formoso/MG com base em espécies neotropicais. Revista Brasileira de Recursos Hídricos, Porto Alegre, v. 19, p. 72-82. 2014.

HOLMQUIST, J.G.; WADDLE, T.J. Predicted macroinvertebrate response to water diversion from a montane stream using two-dimensional hydrodynamic models and zero flow approximation. Ecological Indicators, London, v.28, p.115-124, ago. 2013

IM, D.; KANG, H.; KIM, K-H.; CHOI, S-U. Changes of river morphology and physical fish habitat following weir removal. Ecological Engineering, Amsterdam, v.37, n.6, p.883-892, jun. 2011.

JAY LACEY, R. W.; MILLAR, R. G. Reach scale hydraulic assessment of instream salmonid habitat restoration. Journal of the American Water Resources Association, Herndon, v.40, n.6, p.1631-1644. 2004.

JOWETT, I.G.; DUNCAN, M.J. Effectiveness of 1D and 2D hydraulic models for instream habitat analysis in a braided river. Ecological Engineering, Amsterdam, v.48, p.92-100, nov. 2012.

KASER, D.; GRAF, T.; COCHAND, F.; MCLAREN, R.G.; THERRIEN, R.; BRUNNER, P. Channel representation in physically-based models coupling groundwater and surfasse water: pitfalls and how to avoid them. Ground Water, New York, v.52, v.6, p.827-836. 2014.

KONDOLF, G. M.; LARSEN, E. W.; WILLIAMS, J. G. Measuring and Modeling the Hydraulic Environment for Assessing Instream Flows. North American Journal of Fisheries Management, Lawrence, v. 20, p.1016-1028. 2000.

LEE, J. H.; KIL, J. T.; JEONG, S. Evaluation of physical fish habitat quality enhancement designs in urban streams using a 2D hydrodynamic model. Ecological Engineering, Amsterdam, v.36, p.1251-1259. 2010.

LORANGER, J.; KENNER, S. Comparison of One- and Two-Dimensional Hydraulic Habitat Models for Simulation of Trout Stream Habitat. In: SEHLKE, G.; HAYES, D. F.; STEVENS, D. K. Critical transitions in water and environmental resources management. Salt Lake City, Utah, U.S.: American Society of Civil Engineers, 2004. 1-10p.

MARSILI-LIBELLI, S.; GIUSTI, E.; NOCITA, A. A new instream flow assessment method based on fuzzy habitat suitability and large scale river modeling. Environmental Modelling and Software, Kidlington, v. 41, p.27-38, mar. 2013.

MILHOUS, R.T.; UPDIKE, M.A.; SCHNEIDER, D.M. Physical habitat simulation reference manual - Version II. Instream Flow Information Paper $n^{\circ} 26$, Biological Report 89. US Fish and Wildlife Service: Fort Collins, Colorado. 1989.

MILLIDINE, K.J.; MALCOLM, I.A.; GIBBINS, C.N.; FRYER, R.J.; YOUNGSON, A.F. The influence of canalisation on juvenile salmonid habitat. Ecological Indicators, Amsterdam, v.23, p.262-273, December. 2012.

OH, K.; JEONG, S.; LEE, J.; SEO, H.; PARK, C. A Comparative Study on Fish Physical Habitat Simulation Model. In: WORLD ENVIRONMENTAL AND WATER RESOURCES CONGRESS, 2008, Honolulu. Proceedings... Honolulu: American Society of Civil Engeneers, 2008. 
PARASIEWICZ, P.; CASTELLI, E.; ROGERS, J.N.; PLUNKETT, E. Multiplex modeling of physical habitat for endangered freshwater mussels. Ecological Modelling, New York, v. 228, p.66-75, 2012.

PELISSARI, V.B. Vazão ecológica de rios: Estudo de caso: Rio Timbuí, Santa Teresa, ES. 2000. 151f. Thesis (Master's degree in Environmental Engineering), Universidade Federal do Espírito Santo, Vitória, 2000.

SANTOS, H. A.; CHAVES, C.; LEAL, C. G.; POMPEU, P. S. An application of PHABSIM in Velhas river, Southeast Brazil. In: IAHR CONGRESS, 33., 2009, Vancouver. Proceedings... Madrid: IAHR, 2009. p. 1-6.

SILVA, E. R. Abordagem multicriterial difusa como apoio ao processo decisório para a identificação de um regime de vazões ecológicas no baixo curso do Rio São Francisco. 2010. 170f. Thesis (Master's degree in Urban Environmental Engineering) - Universidade Federal da Bahia, Salvador, 2010.

SOUZA, M. de; PINTO, F. G. da S.; FRUET, T. K.; PIANA, P. A.; MOURA, A. C. de. Water quality indicators for environmental and resistance profile of Escherichia coli strains isolated in Rio Cascavel, Paraná, Brazil. Engenharia Agrícola, Jaboticabal, v.34, n.2, p.352-362, mar./abr. 2014.

STEFFLER, P.; BLACKBURN, J. Two-dimensional depth averaged model of river hydrodynamics and fish habitat. Alberta: University of Alberta, 2002. 120p.

TONINA, D.; JORDE, K. Hydraulic Modelling Approaches for Ecohydraulic Studies: 3D, 2D, 1D and Non-Numerical Models. In: MADDOCK, I.; HARBY, A.; KEMP, P.; WOOD, P. Ecohydraulics: an integrated approach. Chichester: John Wiley and Sons, 2013.

TUHTAN, J.; NOACK, M.; WIEPRECHT, S. Estimating stranding risk due to hydropeaking for juvenile European grayling considering river morphology. KSCE Journal of Civil Engineering, Seoul, v.16, n.2, p.197-206. 2012.

UNITED STATES GEOLOGICAL SURVEY (USGS). PHABSIM for Windows: User's Manual and Exercises. Midcontinent Ecological Science Center, Fort Collins, CO, 2001. 299 p.

VOROSMARTY, C.J.; MCINTYRE, P.B.; GESSNER, M.O.; DUDGEON, D.; PRUSEVICH, A.; GREEN, P.; GLIDDEN, S.; BUNN, S.E.; SULLIVAN, C.A.; REIDY LIERMANN, C.; DAVIES, P.M. Global threats to human water security and river biodiversity. Nature, London, v.467, p.555561, September. 2010.

WADDLE, T.; STEFFLER, P. R2D_Mesh. Mesh generation program for River2D two dimensional depth averaged finite element. Introduction to mesh generation and user's manual. Fort Collins: Geological Survey, 2002. 31 p.

WADDLE, T.J.; STEFFLER, P.; GHANEM, A.; KATOPODIS, C.; LOCKE, A. Comparison of one and two-dimensional open channel flow models for a small habitat stream. Rivers, New York, v.7, n.3, p.205-220, 2000.

YI, Y.; WANG, Z.; YANG, Z. Impact of the Gezhouba and Three Gorges Dams on habitat suitability of carps in the Yangtze River. Journal of Hydrology, Amsterdam, v.387, n.3, p.283291, jun. 2010.

ZALEWSKI, M. Ecohydrology for compensation of Global Change. Brazilian Journal of Biology, São Carlos, v.70, n.3, p.689-695, 2010. 